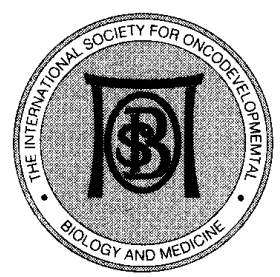

\title{
Changing of the Guard at the Editorial Level!
}

\author{
Jean-Pierre Mach
}

Dear ISOBM members,

Dear faithful readers of Tumor Biology,

After 5 years of excellent management of our Journal, Professor Sabine von Kleist, has decided to retire from the responsibility of editor-in-chief of Tumor Biology. Professor von Kleist accepted the position of editor-inchief at the end of 1994, succeeding Professor Munro Neville, editor-in-chief, and Aaron Malkin, managing editor. Professor von Kleist managed the Journal alone with a strong hand, while maintaining an excellent relationship with our publisher, Karger in Basel. Despite her numerous other responsibilities as dean of the Medical Faculty and vice rector at the University of Freiburg in Breisgau, Professor von Kleist always did a very efficient job, with a careful peer review system and no publication delays. Under her editorship, the submission rate of manuscripts increased steadily and Tumor Biology improved its international status with articles published from over twenty-five different countries. To have a journal allowing truly international scientific exchange was a wish from the founder of ISOBM, the late Professor Hidematsu Hirai. This wish was perfectly fulfilled by Professor von Kleist.

I am pleased to announce that the Board of ISOBM has been able to select two highly motivated members of our Society to take over the responsibility of our journal: Professor Torgny Stigbrand, as editor-in-chief, and Dr. Phil Rye, as managing editor. Torgny Stigbrand is a medical doctor and Professor at the University of Umeå in the north of Sweden. $\mathrm{He}$ is a very dynamic person as demonstrated by his important role in the organization of last year's highly successful ISOBM meeting. He has an excellent record of publications in the field of tumor markers, monoclonal antibodies for tumor targeting and experimental oncology. Phil Rye is a PhD graduate from Leicester University, now working at the Norwegian Radium Hospital in Oslo. His field of research includes the biochemical characterization of tumor markers with emphasis on carbohydrates. He has demonstrated high professional expertise and dedication in the editing of several TD workshop reports and has been very active in raising the Society's profile on the Internet. We believe that Torgny Stigbrand and Phil Rye have the complementary skills required to bring Tumor Biology to ever higher levels of international recognition, and to this aim we wish them great success.

Thank you Sabine for an excellent job!

Good luck Torgny and Phil for a successful collaboration.

Jean-Pierre Mach President ISOBM

\begin{tabular}{ll}
\hline KARGER & ( 1999 S. Karger AG, Basel \\
Fax +41 61 306 1234 & 1010-4283/99/0206-0293\$17.50/0 \\
$\begin{array}{l}\text { E-Mail karger@karger.ch } \\
\text { www.karger.com }\end{array}$ & $\begin{array}{l}\text { Accessible online at: } \\
\text { www.karger.com/journals/tbi }\end{array}$
\end{tabular}

